\title{
VEGETATIVE COMPATIBILITY GROUPS OF PHYSIOLOGICAL RACES OF PYRICULARIA GRISEA IN Egypt
}

\author{
EL-WAHSH, S. M. ${ }^{1}$, R. A. ARAFA ${ }^{1}$, A. A. EMERAN ${ }^{2}$ and S. F. MASHAAL ${ }^{2}$ \\ 1. Dept. of Rice Pathology Research, Sakha, Plant Pathology Research Institute, ARC, \\ 2. Dept. of Agricultural Botany, Faculty of Agriculture, Kafrelsheikh University, Egypt
}

(Manuscript received 6 February 2013)

\begin{abstract}
One hundred forty Pyricularia grisea isolates were collected from the six main rice growing governorates; Kafrelsheikh, Beheira, Sharkia, Gharbia, Dakahlia and Damietta, and from different research stations during 2008, 2009 and 2010 growing seasons. The isolates were identified to their group races as IA (1); IB (12); IC (15); ID (45); IE (1); IF (4); IG (22); IH (32) and II (8) using the international differential varieties under greenhouse conditions. Vegetative compatibility groups (VCGs) among the races were studied through producing nitrate nonutilizing (nit) mutants for the races on chlorate minimal medium (CMM). The results revealed that the nit mutants were grouped into eight VCGs. VCG 1 included members of the IB race group (70.59\%). VCG 2 included members of IC race group with $87.5 \%$ and two isolates were identified as IH and II. The largest group, VCG 3 included 44 isolates, most of these isolates were identified as ID (86.36\%). All isolates in VCG 4 were identified as IF. $95.65 \%$ of isolates in VCG 5 represented IG and one belonged to II (4.35\%). All isolates in VCG 6 corresponded to IH (96.43\%), and only one as ID. VCG 7 included eight isolates, 5 isolates represented ID and one each of IG, IF and IH. Only one isolate was identified as IE race group in VCG 8 . The reaction among different nit mutants was examined using scanning electron microscope and revealed that heterokaryon, incompatibility and inhibition zone were observed. This investigation revealed that the correspondence between VCGs and races ranged from 62.5 to $100 \%$; however, the latter percentage was relevant to very small number of isolates.
\end{abstract}

Key words: Rice blast, Pyricularia grisea, VCGs, Heterokarion and Egypt.

\section{INTRODUCTION}

Rice (Oryza sativa L.) is the second staple food crop after wheat in Egypt, and is very important for local consumption, and for exportation. Paddy production is about 5 million tons and the national yield productivity is about $4.03 \mathrm{t} /$ feddan (9.6 t/ha) (RRTC, 2011). The rice blast is widespread and damaging disease in most rice growing areas of the world (Ou, 1985). Under Egyptian conditions, rice blast disease may affect annual rice production by about $5 \%$ in normal or mildly infected seasons. In epidemic seasons, yield losses may reach as high as 30-50\% (Sehly et al., 2002). Vegetative compatibility grouping (VCG) is a useful tool for identifying genetic diversity among fungal isolates (Correll et al., 1987; Leslie, 1993 and Fourie et al., 
2009). Many fungi can convert nitrate to ammonium by the action of nitrate reductase (Garraway and Eveans, 1984). Meanwhile, nitrate reductase can convert chlorate to chlorite, a fungitoxic substance. So, wild strains which can assimilate nitrate, are sensitive to chlorate, but nitrate nonutilizing (nit) mutants are resistant to chlorate. Many investigators studied the race population using VCGs as a means to measure the pathogen diversity. The multiple-locus base for the VCG subdivisions means that applying one test, the relationship at multiple loci is being assessed and permit to determine identities relatively quickly (Desjardins et al., 1992). However, some others reported that VCGs are not useful in determining the degree of relatedness if the two isolates were not identical (Leslie, 1993). Busso et al. (2007) studied VCGs among $P$. grisea isolates which were isolated from wheat. Mutants which were unable to use sodium nitrate as nitrogen source, were obtained with potassium chlorate and were divided into two VCGs. Correll et al. (2009) characterized isolates of P. oryzae using different tests including DNA fingerprinting with MGR 586 and vegetative compatibility test. These isolates were classified into four distinct VCGs with complete correspondence of the four MGR 586 DNA fingerprinting groups. Motallebi et al. (2009) studied VCGs in 75 monoconidial isolates of Magnaporthe grisea strains complex obtained from rice and some grasses from north Iran. All the isolates and eight standard mating type tester isolates were analyzed with complementation tests using nit mutants to determine VCGs and genetic relationship between the two groups of isolates. All rice isolates were grouped into four VCGs, while all grasses isolates belonged to three VCGs. In addition, there was no correlation between field isolates and standard mating type isolates. Leslie (1993) reported that an alternative is to create specific tester strain for each VCG that needs to be detected. The tester strain would have one recessive marker that could be selected against and one dominant marker that could be selected. The use of VCGs may be particularly helpful in characterization and interpretation of diversity within and between rice blast pathogen populations in many rice growing regions of the world where cost and laboratory facilities may limit the number of isolates that can be analyzed by molecular methods. The objectives of this study were to (i) determine the number and distribution of rice blast races in the six Egyptian rice growing governorates using VCG method and determine the relationship between VCGs and physiological races, (ii) investigate the genetic diversity among the populations of $P$. grisea isolates with respect to vegetative compatibility groups. 


\section{MATERIALS AND METHODS}

\section{1- Fungal isolates and race identification}

A total of one hundred forty $P$. grisea isolates were collected from 19 rice entries, namely, Sakha 101, Sakha 104, Giza 159, Giza 171, Nishihikari, Fukunishiki, BL-1, M 202, M201, Pi.No4, Usen, Reiho, B9C-MD-3-3, B46-1B-PN-3, IR70554-48-1-2, IRTP21662(IRB-LA-A), Hybrid 2, IR-82225-11-3-1and IR-82737-B-182 from six rice growing governorates; Kafrelsheikh, Beheira, Damietta, Gharbia, Dakahlia and Sharkia during 2008, 2009 and 2010 growing seasons. The isolates were identified to races on international differential varieties (IDVs) namely: Raminad str.3, Zenith, NP-125, Usen, Dular, Kanto 51, CI 8970 S and Caloro (Atkins et al. 1967) under greenhouse conditions as described by Sehly et al. (2009).

\section{Nitrate nonutilizing mutant production}

The blast isolates were identified and classified on the IDVs under greenhouse conditions to race groups. Three hyphal tips were transferred from culture representing each race group to $9 \mathrm{~cm}$ diameter Petri dishes containing chlorate minimal medium (CMM) according to Correll et al., (1987) and incubated at $27{ }^{\circ} \mathrm{C}$ for 3 - 4 weeks. Sectors that grew as thin, expansive colonies with little or without aerial mycelium were designated as nit mutant. Sectors were transferred to minimal medium (Correll et al., 1987) containing sodium nitrate as a nitrogen source and examined after ten to fifteen days.

\section{Selection and tester production}

Nine testers of the nit mutant isolates each represented one of the nine race groups (IA-II) were selected and tested. Three hyphal tips from selected nit mutants were transferred to each Petri dish containing minimal medium as described by Puhala and Hummel (1983). The dishes were incubated at $27{ }^{\circ} \mathrm{C}$ for 15 days. The hyphal tip was selected from the best colony and transferred on a piece of sterilized filter paper disc on minimal medium. Filter paper discs were transferred individually into sterilized Petri dishes after the complete growth of the nit mutant. About one week later, the dried filter papers, having the nit mutant (testers) were cut into small pieces. Pieces obtained from each tester were altogether introduced into a plastic vial and kept at $20^{\circ} \mathrm{C}$ for long term storage (Metkwatanakarn et al., 1999).

\section{Vegetative complementary test}

Complementation is evident by dense aerial mycelium where the two thin nit mutant colonies contact. Vegetative compatible nit mutants may complement one another by forming a heterokaryon on minimal medium i.e. dense aerial growth develops where mycelia of the two nit mutant colonies come in contact, anastomose and form a heterokaryon (Correll et al., 1987). Complementation tests were conducted on minimal medium in Petri dishes. The selected testers (nine testers) and 
the other nit mutants of $P$. grisea races were grown on minimal medium for 10-15 days. The nit mutant of each tester was placed in the center of a $9-\mathrm{cm}$ diameter Petri dish containing minimal medium. Four nit mutants for the races were transferred and distributed equidistantly apart around the tester with three replications at least. These daisy parings were incubated at $27{ }^{\circ} \mathrm{C}$ for $30-35$ days. Complementation indicating heterokaryon formation was recognized as a line of dense aerial mycelial growth where two nit mutants grew together on minimal medium (Correll et al., 1987). Lack of complementation may mean that the mutants are not complementary, that the nit mutant races are in different VCGs, or that the nit mutants are unable to form a heterokaryon in which complementation can occur. Complementation score was recorded after 30-35 days as follow:-

$$
\begin{array}{ll}
0=\text { No reaction } & 1=\text { Little or no aerial mycelium } \\
2=\text { Abundant aerial mycelium } & 3=\text { Very abundant aerial mycelium }
\end{array}
$$

In addition, inhibition zone (IZ) reaction was also considered

\section{5- Scanning Electron Microscope (SEM)}

The contact area between the pairings on Petri dishes was examined using scanning electron microscope at Electron Microscope Unit (EMU), Faculty of medicine, Tanta University, Egypt.

\section{RESULTS AND DISCUSSION}

\section{1- Physiological races}

The distribution of the 140 isolates of $P$. grisea identified as race groups during in three seasons (2008-2010) was presented in Table (1).

Table 1. Number and percentage of Pyricularia grisea race groups collected from different rice growing governorates during 2008- 2010 seasons.

\begin{tabular}{|c|c|c|c|c|c|c|c|c|}
\hline \multirow{2}{*}{$\begin{array}{c}\text { Race } \\
\text { group }\end{array}$} & \multicolumn{9}{|c|}{ Season } & \multirow{2}{*}{2010} & & Total & $\begin{array}{c}\text { Percentage } \\
\text { of common } \\
\text { race }\end{array}$ \\
\cline { 2 - 8 } & Number & $\%$ & Number & $\%$ & Number & $\%$ & & \\
\hline IA & 0 & 0 & 1 & 1.49 & 0 & 0 & 1 & 0.69 \\
\hline IB & 3 & 6.52 & 3 & 4.48 & 6 & 19.35 & 12 & 8.6 \\
\hline IC & 2 & 4.2 & 8 & 11.94 & 4 & 12.9 & 14 & 10.0 \\
\hline ID & 1 & 2.17 & 25 & 37.31 & 19 & 61.2 & 45 & 32.1 \\
\hline IE & 1 & 2.17 & 0 & 0 & 0 & 0 & 1 & 0.69 \\
\hline IF & 4 & 8.70 & 0 & 0 & 0 & 0 & 4 & 2.78 \\
\hline IG & 7 & 15.22 & 14 & 20.9 & 1 & 3.23 & 22 & 15.7 \\
\hline IH & 19 & 41.30 & 14 & 20.9 & 0 & 0 & 33 & 23.6 \\
\hline II & 8 & 17.39 & 0 & 0 & 0 & 0 & 8 & 5.7 \\
\hline Total & 45 & & 65 & & 30 & & 140 & \\
\hline
\end{tabular}




\section{2- Complementation test reaction}

One hundred forty blast isolates were grown to produce nit mutants, on chlorate minimal medium. The chlorate resistant sectors were transferred on to minimal medium free from potassium chlorate $\left(\mathrm{KClO}_{3}\right)$. Out of the selected sectors, one was selected for complementary test. One out of five reactions (0, 1, 2, 3 and inhibition zone) was obtained through complementary test among different nit mutants (one for each 140 nit mutants for $P$. grisea races) and its testers. The nit mutant producing dense aerial wild type mycelia when two nit mutants were paired together and mycelia growth of their colonies were met and formed heterokaryons giving reaction after four to five weeks.

Data in Table (2) show that the nit mutant races were grouped into eight VCGs. Group 1 (VCG 1) recovered all IB blast races (12 races represented $70.59 \%$ from the total of VCG 1 races); two races identified IH group (11.76 \%) and one race for each II, IA and ID as $5.88 \%$ for each (Table 2). Most of races in Group 2 represented IC race group with $(87.5 \%)$. The biggest group VCG 3 included 44 isolates; most of these isolates were identified as ID race group (86.36\%). All races in VCG 4 belonged to IF race group. Twenty two out of 23 isolates of VCG 5 belonged to IG group race as (95.65\%) and one represented II group race. For VCG 6, most of these isolates in this group were in IH race group as (96.43\%). The seventh group as (VCG 7) including eight isolates, 5 represented ID race group and one for each of IG, IF and IH group races. Only one isolate was identified as IE-7 race, in VCG 8.

The complementation among different tested isolates in the same VCG ranged from 70.59 in group 1 to $100 \%$ in group 4 and group 8 except group 7 which showed complementation at $62.5 \%$. Members of the IB group race were found in four governorates (Dakahlia, Beheira, Kafrelshiekh and Gharbia). While, IC group race was distributed to three governorates (Beheira, Kafrelsheikh and Gharbia). The biggest group race ID, in addition to IG and IH group races were distributed in five rice governorates. VCG4 and VCG 8 which included IF and IE group race, respectively, came from Kafrelsheikh only (Table2). Similar studies were carried out by Correll et al. (2000), Mosa-Nejad et al. (2005), Javan-Nikkhah et al. (2007), Amir-Dehi et al. (2008) and Motallebi et al. (2009) on M. grisea isolates and different VCGs were identified. 
Table 2. Distribution of vegetative compatibility groups of Pyricularia grisea races and its pathotypes collected from different locations during 2008-2010 seasons.

\begin{tabular}{|c|c|c|c|c|}
\hline No. of VCG & Isolate & Location & Race & Year \\
\hline \multirow[t]{17}{*}{ VCG 1} & 3 & Beheira & IB-61 & 2008 \\
\hline & 25 & Dakahlia & IB-61 & 2008 \\
\hline & 29 & Dakahlia & IB-63 & 2008 \\
\hline & 54 & Gharbia & IB-63 & 2009 \\
\hline & 86 & Ghabia & IB-61 & 2009 \\
\hline & 87 & Gharbia & IB-29 & 2009 \\
\hline & 115 & Gharbia & IB-47 & 2010 \\
\hline & 118 & Kafrelsheikh & IB-41 & 2010 \\
\hline & 121 & Beheira & IB-41 & 2010 \\
\hline & 125 & Kafrelsheikh & IB-33 & 2010 \\
\hline & 133 & Kafrelsheikh & IB-33 & 2010 \\
\hline & 136 & Kafrelsheikh & IB-41 & 2010 \\
\hline & 1 & Beheira & $\mathrm{IH}-1$ & 2008 \\
\hline & 22 & Dakahlia & $\mathrm{IH}-1$ & 2008 \\
\hline & 28 & Sharkia & II-1 & 2008 \\
\hline & 76 & Kafrelsheikh & IA-41 & 2009 \\
\hline & 91 & Kafrelsheikh & ID-5 & 2009 \\
\hline \multirow[t]{16}{*}{ VCG 2} & 2 & Beheira & IC-31 & 2008 \\
\hline & 39 & Kafrelsheikh & IC-32 & 2008 \\
\hline & 47 & Kafrelsheikh & IC-27 & 2009 \\
\hline & 56 & Kafrelsheikh & IC-13 & 2009 \\
\hline & 92 & Gharbia & IC-13 & 2009 \\
\hline & 97 & Kafrelsheikh & IC-9 & 2009 \\
\hline & 98 & Kafrelsheikh & IC-12 & 2009 \\
\hline & 99 & Beheira & IC-13 & 2009 \\
\hline & 110 & Kafrelsheikh & IC -13 & 2009 \\
\hline & 111 & Kafrelsheikh & IC-13 & 2009 \\
\hline & 137 & Kafrelsheikh & IC-13 & 2010 \\
\hline & 138 & Kafrelsheikh & IC-29 & 2010 \\
\hline & 141 & Kafrelsheikh & IC-13 & 2010 \\
\hline & 142 & Kafrelsheikh & IC-9 & 2010 \\
\hline & 4 & Kafrelsheikh & $\mathrm{IH}-1$ & 2008 \\
\hline & 13 & Kafrelsheikh & II-1 & 2008 \\
\hline \multirow[t]{26}{*}{ VCG 3} & 35 & Sharkia & ID-7 & 2008 \\
\hline & 49 & Kafrelsheikh & ID-15 & 2009 \\
\hline & 53 & Gharbia & ID-9 & 2009 \\
\hline & 61 & Gharbia & ID-5 & 2009 \\
\hline & 64 & Gharbia & ID-13 & 2009 \\
\hline & 79 & Kafrelsheikh & ID-11 & 2009 \\
\hline & 80 & Kafrelsheikh & ID-13 & 2009 \\
\hline & 81 & Beheira & ID-13 & 2009 \\
\hline & 89 & Gharbia & ID-13 & 2009 \\
\hline & 93 & Beheira & ID-10 & 2009 \\
\hline & 95 & Kafrelsheikh & ID-13 & 2009 \\
\hline & 96 & Kafrelsheikh & ID-15 & 2009 \\
\hline & 101 & Gharbia & ID-9 & 2009 \\
\hline & 104 & Gharbia & ID-13 & 2009 \\
\hline & 106 & Beheira & ID-13 & 2009 \\
\hline & 107 & Kafrelsheikh & ID-13 & 2009 \\
\hline & 108 & Beheira & ID-13 & 2009 \\
\hline & 109 & Kafrelsheikh & ID-13 & 2009 \\
\hline & 112 & Beheira & ID-13 & 2009 \\
\hline & 113 & Beheira & ID-13 & 2009 \\
\hline & 114 & Sharkia & ID-13 & 2010 \\
\hline & 116 & Kafrelsheikh & ID-5 & 2010 \\
\hline & 117 & Kafrelsheikh & ID-13 & 2010 \\
\hline & 119 & Beheira & ID-13 & 2010 \\
\hline & 120 & Beheira & ID-13 & 2010 \\
\hline & 122 & Dakahlia & ID-13 & 2010 \\
\hline
\end{tabular}


Table 2. continued

\begin{tabular}{|c|c|c|c|c|}
\hline No . of VCG & Isolate No. & Location & Race & Year \\
\hline & 123 & Dakahlia & ID-13 & 2010 \\
\hline & 124 & Kafrelsheikh & ID-13 & 2010 \\
\hline & 126 & Sharkia & ID-13 & 2010 \\
\hline & 128 & Sharkia & ID-13 & 2010 \\
\hline & 129 & Sharkia & ID-13 & 2010 \\
\hline & 130 & Kafrelsheikh & ID-13 & 2010 \\
\hline & 131 & Gharbia & ID-13 & 2010 \\
\hline & 132 & Kafrelsheikh & ID-1 & 2010 \\
\hline & 134 & Kafrelsheikh & ID-13 & 2010 \\
\hline & 135 & Kafrelsheikh & ID-13 & 2010 \\
\hline & 139 & Kafrelsheikh & ID-13 & 2010 \\
\hline & 140 & Kafrelsheikh & ID-13 & 2010 \\
\hline & 15 & Kafrelsheikh & II-1 & 2008 \\
\hline & 21 & Dakahlia & II-1 & 2008 \\
\hline & 23 & Dakahlia & II-1 & 2008 \\
\hline & 24 & Dakahlia & II-1 & 2008 \\
\hline & 26 & Dammieta & II-1 & 2008 \\
\hline & 77 & Dakahlia & IH-1 & 2009 \\
\hline \multirow{3}{*}{ VCG 4} & 5 & Kafrelsheikh & IF-3 & 2008 \\
\hline & 16 & Kafrelsheikh & IF-1 & 2008 \\
\hline & 31 & Kafrelsheikh & IF-3 & 2008 \\
\hline \multirow[t]{23}{*}{ VCG5 } & 8 & Kafrelsheikh & IG-1 & 2008 \\
\hline & 12 & Kafrelsheikh & IG-2 & 2008 \\
\hline & 18 & Beheira & IG-2 & 2008 \\
\hline & 19 & Beheira & IG-1 & 2008 \\
\hline & 37 & Sharkia & IG-1 & 2008 \\
\hline & 43 & Kafrelsheikh & $\mathrm{IG}-1$ & 2008 \\
\hline & 46 & Kafrelsheikh & IG-1 & 2008 \\
\hline & 48 & Kafrelsheikh & IG-2 & 2009 \\
\hline & 51 & Gharbia & $\mathrm{IG}-1$ & 2009 \\
\hline & 52 & Gharbia & IG-1 & 2009 \\
\hline & 58 & Kafrelsheikh & IG-1 & 2009 \\
\hline & 62 & Gharbia & IG-1 & 2009 \\
\hline & 65 & Sharkia & IG-1 & 2009 \\
\hline & 66 & Sharkia & IG-1 & 2009 \\
\hline & 68 & Sharkia & $\mathrm{IG}-1$ & 2009 \\
\hline & 71 & Sharkia & $\mathrm{IG}-1$ & 2009 \\
\hline & 73 & Kafrelsheikh & $\mathrm{IG}-1$ & 2009 \\
\hline & 74 & Kafrelsheikh & IG-1 & 2009 \\
\hline & 78 & Dakahlia & IG-1 & 2009 \\
\hline & 83 & Kafrelsheikh & IG-1 & 2009 \\
\hline & 103 & Sharkia & $\mathrm{IG}-1$ & 2009 \\
\hline & 127 & Sharkia & IG-1 & 2010 \\
\hline & 14 & Kafrelsheikh & II-1 & 2008 \\
\hline \multirow[t]{15}{*}{ VCG 6} & 7 & Kafrelsheikh & IH-1 & 2008 \\
\hline & 9 & Kafrelsheikh & $\mathrm{IH}-1$ & 2008 \\
\hline & 10 & Kafrelsheikh & IH-1 & 2008 \\
\hline & 11 & Kafrelsheikh & $\mathrm{IH}-1$ & 2008 \\
\hline & 20 & Beheira & IH-1 & 2008 \\
\hline & 27 & Dakahlia & IH-1 & 2008 \\
\hline & 30 & Sharkia & IH-1 & 2008 \\
\hline & 32 & Kafrelsheikh & $\mathrm{IH}-1$ & 2008 \\
\hline & 33 & Kafrelsheikh & IH-1 & 2008 \\
\hline & 34 & Kafrelsheikh & IH-1 & 2008 \\
\hline & 36 & Sharkia & $\mathrm{IH}-1$ & 2008 \\
\hline & 40 & Kafrelsheikh & IH-1 & 2008 \\
\hline & 41 & Kafrelsheikh & $\mathrm{IH}-1$ & 2008 \\
\hline & 44 & Kafrelsheikh & IH-1 & 2008 \\
\hline & 45 & Kafrelsheikh & IH-1 & 2008 \\
\hline
\end{tabular}


Table 2. continued

\begin{tabular}{|l|l|l|l|l|}
\hline No . of VCG & $\begin{array}{l}\text { Isolate } \\
\text { No. }\end{array}$ & Location & Race & Year \\
\hline \multirow{4}{*}{ VCG 6 } & 50 & Gharbia & IH-1 & 2009 \\
\cline { 2 - 5 } & 55 & Kafrelsheikh & IH-1 & 2009 \\
\cline { 2 - 5 } & 57 & Kafrelsheikh & IH-1 & 2009 \\
\cline { 2 - 5 } & 59 & Kafrelsheikh & IH-1 & 2009 \\
\cline { 2 - 5 } & 60 & Kafrelsheikh & IH-1 & 2009 \\
\cline { 2 - 5 } & 63 & Gharbia & IH-1 & 009 \\
\cline { 2 - 5 } & 67 & Sharkia & IH-1 & 2009 \\
\cline { 2 - 5 } & 69 & Sharkia & IH-1 & 2009 \\
\cline { 2 - 5 } & 70 & Sharkia & IH-1 & 2009 \\
\cline { 2 - 5 } & 72 & Sharkia & IH-1 & 2009 \\
\cline { 2 - 5 } & 85 & Beheira & IH-1 & 2009 \\
\cline { 2 - 5 } & 102 & Sharkia & IH-1 & 2009 \\
\cline { 2 - 5 } & 84 & Beheira & ID-15 & 2009 \\
\hline \multirow{5}{*}{ VCG 7 } & 6 & Kafrelsheikh & IH-1 & 2008 \\
\cline { 2 - 5 } & 38 & Kafrelsheikh & IF-3 & 2008 \\
\cline { 2 - 5 } & 42 & Kafrelsheikh & IC-29 & 2008 \\
\cline { 2 - 5 } & 90 & Beheira & ID-13 & 2009 \\
\cline { 2 - 5 } & 94 & Beheira & ID-15 & 2009 \\
\cline { 2 - 5 } & 100 & Beheira & ID-15 & 2009 \\
\cline { 2 - 5 } & 105 & Gharbia & ID-13 & 2009 \\
\cline { 2 - 5 } & 144 & Kafrelsheikh & ID-9 & 2010 \\
\hline VCG 8 & 17 & Kafrelsheikh & IE-7 & 2008 \\
\hline
\end{tabular}

VCGs $=$ Vegetative Compatibility Groups

\section{3- Scanning electron microscope and appearance on media}

The reaction among different nit mutants visually differed. Figure $1 \mathrm{~A}$ illustrates that nit mutant for blast isolates (number 39) was highly compatible with its tester (nit mutant. 76) on minimal medium forming a clear and dense aerial mycelium in the contact area and robust heterokaryon formation was observed. Under scanning electron microscope (SEM) in Fig. 1 B the aerial mycelium appeared with hyphal anastomosis formed between distinct mycelia in contacted nit mutants. Vegetative compatibility systems generally act to restrict the transfer of nuclear and cytoplasmic elements during growth. Most studies of vegetative compatibility have focused on the fusion (anastomosis) of hyphae rather than on the fusion of protoplast. The work done with fused protoplast is quite interesting, however, since the heterokaryons formed following protoplast fusion appear to be significantly different from those formed following hyphal anastomosis (Stasz et al., 1989). Anastomosis formation and the cytological events involved have been studied extensively in ascomycetes and basidiomycetes, (Leslie, 1993). Chen and Wu (1977) mentioned that hyphal anastomosis in $P$. oryzae occurs naturally in the lower epidermal cells and in the vascular bundles of young lesions on rice. In those cells, the invading blast fungus is active. A fusion aperture of $0.2-0.6 \mu \mathrm{m}$ in diameter is formed allowing the migration 
or exchange of nuclei and cytoplasm between two anastamosing hyphal cells. Also, Correll et al. (2000) reported that anastomosis state, the nucleus of a strain migrated into the cell of another strain during plasmogamy to produce a heterokaryon mycelium or heterokaryon cell and occasionally to become diploid after fusing, so anastomosis is considered as a source of recombination or variability.
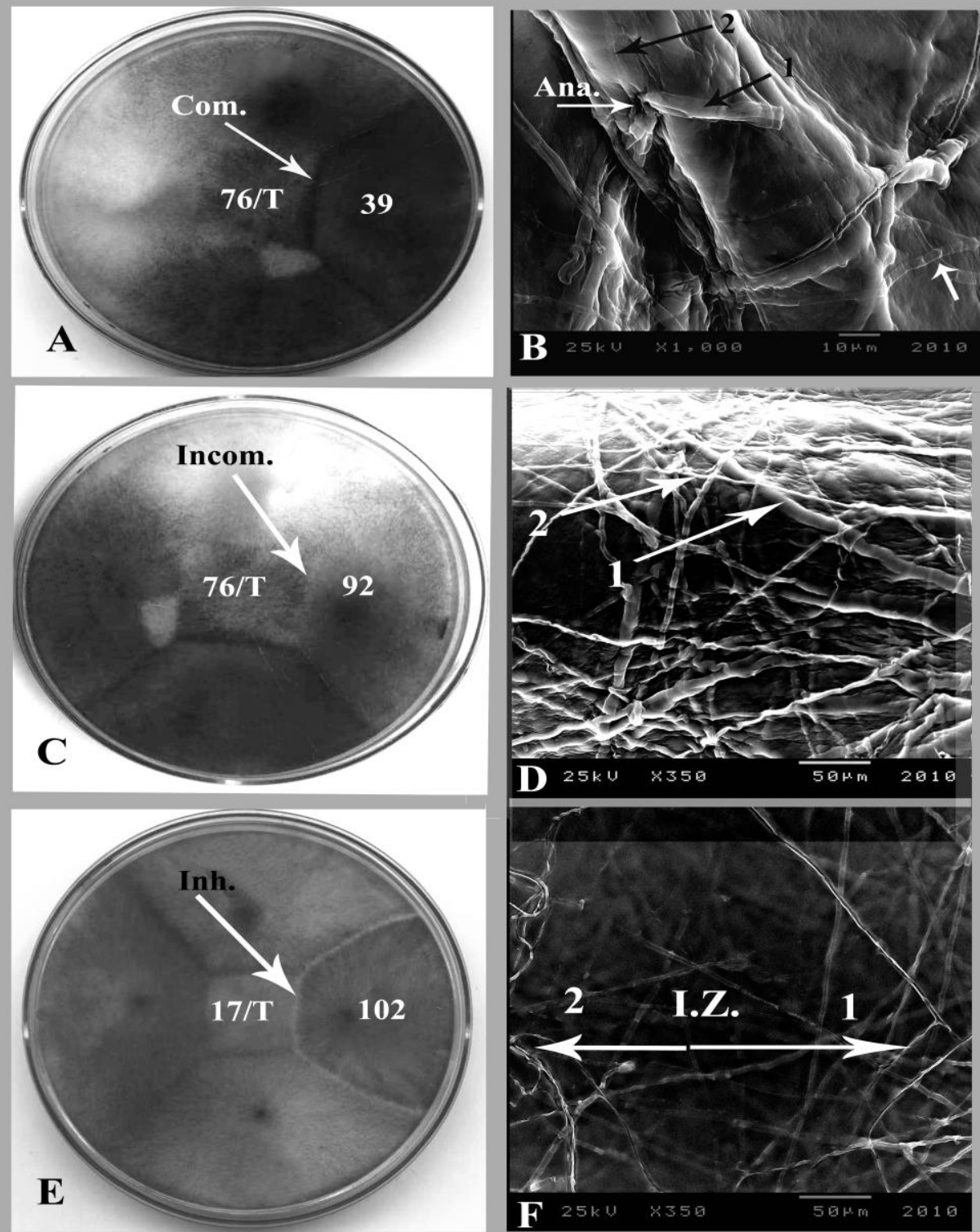

Fig. 1. Photos of vegetative compatibility groups test for nit mutants of some isolates of Pyricularia grisea on Petri dishes and scanning electron microscope, examined different reactions among them as $A, B, C, D, E$ and $F$.

Com. = Compatibility

Incom. $=$ Incompatibility
Ana. $=$ Anastomosis

Inh. = Inhibition zone 
In Figure $(1, C)$ illustrates that the same previous tester was incompatible with another nit mutant (92); the mycelia did not interact with the nit mutant mycelia and developed without the formation of aerial mycelium. In Figure $(1, D)$, the contact area, the two distinct overlapped without anastomosis, indicating an incompatible reaction. In Figure $(1, \mathrm{E})$ exhibited an incompatible reaction between nit mutants 17 and 102 with an inhibition zone area. This inhibition zone was free from growing mycelia or contacted mycelia (Fig 1, F). The inhibition zone formed between some isolates on minimal medim, under SEM lethal mycelia exhibited some fusions as a result of some chemicals or allelo-chemicals produced by some blast races and helped to prevent developing mycelia. Also, similar results were obtained by Javan-Nikkhah (2002). Some investigators explained the phenomenon of incompatibility and inhibition zone. Some biochemical features were found to be correlated with the incompatibility reaction including a decrease in RNA production, appearance of new proteins (Boucherie et al. 1981), and increase in proteolytic and other enzymatic activities such as phenoloxidases, malate/NADH dehydrogenase, proteases, and amino acid oxidase. Vegetative incompatibility systems in fungi normally impair genetic exchanges among strains and are under strict control of heterokaryon incompatibility and vegetative incompatibility loci. Natural populations of fungi are generally polymorphic for vegetative incompatibility systems (Leslie, 1993). The barrage zone phenomenon is conceptually the opposite of a prototrophic vegetative compatibility heterokaryon. Barrages occur between vegetatively incompatible strains in many fungi, including Podospora, Neurospora and Cryphonectria.

Table 3. Relationship between vegetative compatibility groups for 140 Pyricularia grisea races and its group races and percentage of compatibility.

\begin{tabular}{|l|c|c|c|}
\hline VCG group & No. of isolates & $\begin{array}{c}\text { Common group } \\
\text { race }\end{array}$ & $\begin{array}{c}\text { Compatibility } \\
\text { percentage for the } \\
\text { common races }\end{array}$ \\
\hline VCG1 & 17 & IB & 70.59 \\
\hline VCG 2 & 16 & IC & 87.5 \\
\hline VCG 3 & 44 & ID & 86.36 \\
\hline VCG 4 & 3 & IF & 100 \\
\hline VCG 5 & 23 & IG & 95.65 \\
\hline VCG 6 & 28 & IH & 96.43 \\
\hline VCG 7 & 8 & ID & 62.5 \\
\hline VCG 8 & 1 & IE & 100 \\
\hline
\end{tabular}


Data in Table (3) summarized the results relevant to the correspondence between VCGs and race groups as identified by differential varieties and VCGs. VCG 4 and VCG8 each had only one race group. This could probably be due to the small number of isolates included in each. The least correspondence percentage was observed in VCG 7 as $62.5 \%$ with reference to ID. This VCG included three other race groups. There are cases where a single group race may belong to several different VCGs. VCGs 3 and 7 showed majorities of race group ID which raises a question about the possible relationship between the two VCGs. This reduces the degree of dependence on VCG as indicative of race groeping. Generally, the degree of correspondence between VCGs and physiological blast races ranged from $62.5 \%$ to $100 \%$. A similar degree of complexity of race and VCG occur within Fusarium oxysporum $f . s p$ lycopresici; in one case, the three known races were found within a single VCG and others where a single race lies in different VCGs (Elias and Schneider, 1991). With the exception of VCGs 1 and 7, a high degree of correspondence was found between race identity and VCGs. So, it is possible to use vegetative compatibility, with some limitations, as a method for primarily identifying and differentiating races of $P$. grisea. However, greater numbers of isolates need to be included in such studies to reach definite conclusion in this respect

\section{REFERENCES}

1. Amir-Dehi E., S. A. Khodaparast and M. Javan Nikkhah. 2008. Vegetative compatibility groups in population of Magnaporthe grisea (Hebert) barr, the causal agent of rice blast in Mazandaran province. J. Agric. Sci., (University of Tabriz), 18(1): 205-213.

2. Atkins, J. G., A. L. Rebert, C. R. Adsir, K. Goto, T. Kozako, R. Yanagida, Y. Yamada and S. Matsumoto. 1967. An international set of rice varieties for differentiating races of Pyricularia oryzae. Phytopathology, 57:298-301.

3. Boucherie, H., C. H. Dupont and J. Bernet. 1981. Polypeptide synthesis during protoplasmic incompatibility in the fungus Podospora anserina. Biochimica et Biophysica Acta, 653:18-26.

4. Busso, C., E. N. Kaneshima, F. A. Franco and M. A. C. Prado. 2007. Genetic and molecular characterization of pathogenic isolates of Pyricularia grisea from wheat (Triticum aestivum Lam.) and triticale ( $x$ Triticosecale Wittmack) in the state of Paraná, Brazil. Revista Iberoamericana de Micología, 24: 167-170. 
5. Chen, J. T. and H. K. Wu. 1977. Hyphal anastomosis in Pyricularia oryzae Cav. Protoplasma, 92: 281-287.

6. Correll, J. C., C. J. R. Klittich and J. F. Leslie. 1987. Nitrate nonutilizing mutant of Fusarim oxysporum and their use in vegetative compatibility tests. Phytopathology, 77:1640-1646.

7. Correll, J. C., E. J. Boza, E. Seyran, R. D. Cartwright, M. K. Currie and F. N. Lee. 2009. Examination of the rice blast pathogen population diversity in Arkansas, USA-Stable or unstable. 217-228 pp. In: Wang, G.L. and B. Valent (eds.), Advances in genetics, genomics and control of rice blast disease. Springer science + Business Media B.V.

8. Correll, J. C., T. L. Harp, J. C. Guerber, R. S. Zeigler, B. liu, R. D. Cartwright and F. N. lee. 2000. Characterization of Pyricularia grisea in the United States using independent genetic and molecular markers. Phytopathology, 90(12):1396-1404.

9. Desjardins, A. E., R. D. Platter, D. D. Shackelford, J. F. Leslie and P. E. Nelson 1992. Heritability of fumonisin $B_{1}$ production in Gibberella fujikuroi mating population A. Appl. Environ. Microbiol., 58:2799-27805.

10. Elias, K. S. and R. W. Schneider. 1991. Vegetative compatibility groups (heterokaryons) in Fusarium oxysporum f. sp. Lycopersici. Phytopathology 81:159-162.

11. Fourie, G, E. T. Steenkamp, T. R. Gordon and A. Viljoen. 2009. Evolutionary relationships among the Fusarium oxysporum f.sp.cubense vegetative compatibility groups. Amer. Soci. Microbiol., 75(14): 4770-4781.

12. Garraway, M. O. and R. C. Eveans. 1984. Fungal Nutrition and Physiology. New York: John Wiley \& Sons, 1-520.

13. Javan-Nikkhah, M. 2002. Investigation on genetic diversity of populations of Magnaporthe grisea (Hebert) Barr, the rice blast fungus, using molecular, pathogenicity and vegetative compatibility characters in Guilan Province. Ph.D. Thesis. University of Tehran, Iran.

14. Javan-NikKhah, M., K. Vahid, I. Y. Manuchehr, M. Sadiqeh, B. Z. Fattaneh and H. R. Q. Ali. 2007. Study on vegetative compatibility and determination of mating type distribution of Magnaporthe grisea population in Iran. Rice Research Institute of Iran - RRII, Rasht (Iran), 37 P.

15. Leslie, J. F. 1993. Fungal vegetative compatibility. Annu. Revi. Phytopathol., 31:127- 150 . 
16. Mekwatanakarn, P., W. Kositratana, T. Phomraksa and R. S. Zeigler. 1999. Sexually ferial Magnaporthe grisea rice pathogens in Thailand. Plant Disease, 83:939-943.

17. Motallebi, P., M. Javan-Nikhah, S. M. Okhovvat, K. B. Fotouhifar and M. Bargnil. 2009. Vegetative compatibility groups within Iranian population of Magnaporthe grisea species complex from rice and some grasses. J. Plant Pathology, 91(2):469-473.

18. Mousa-Nejad, S., M. Javan-Nikkhah and E. M. Goltape. 2005. Characterization of vegetative compatibility groups in Magnaporthe grisea population in Guilan Province, Iran. J. Agric. Sci., 36(2): 305-316.

19. Ou, S. H. 1985. Rice diseases, $2^{\text {nd }}$ edition, Commonwealth Agricultural Bureaux, Central Sales, Franham Royal, UK, 380 pp.

20. Puhalla, J. E. and M. Hummel. 1983. Vegetative compatibility groups with Verticillium dahliae. Phytopathology, 73:1305-1308.

21. RRTC. 2011. Rice Research and Training Center (National Rice Research Program): Final results of 2011 growing season. Sakha, Kafrelsheikh, Egypt.

22. Sehly, M. R., M. S. Nazim and R. A. EL- Shafey. 2009. Host range of Pyricularia grisea in Egypt. J. Agri. Sci. Mansura Univ., 34(4):3869-3882.

23. Sehly, M. R., Z. H. Osman and E. A. Salem. 2002. Rice Diseases. In (Theresa A. Castilloed):: Rice in Egypt. Rice Research and Training Center, Sakha, Kafrelsheikh, Egypt. 198-247. pp.

24. Stasz, T. E., G. E. Harman and M. L. Gullion. 1989. Limited vegetative compatibility following intra-and interspecific protoplast fusion in Trichoderma. Experimental Mycology, 13:364-371. 


\title{
مجموعات التوافق الخضرى لسلالات اللفحة الفسيولوجية
}

\section{للفطر Pyricularia grisea فى مصر}

\author{
صلاح محمود الوحش1، رمضان أحمد عرفه1، عمرو على عمران 2، السيد فهمى مشعل2 \\ 1 - قسم بحوث /مراض الارز - سذا- معه بحوث /مراض النباتات- مركز البحوث الزر/عبة - مصر

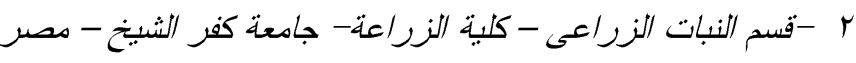 \\ المستخلص
}

تم تجميع 140 عزلة من الفطر Pyricularia grisea المسبب لمرض اللفحة فى الارزوذلك من

محافظات زر اعة الارز الاساسية وهى كفر الثيخ و البحيره والثرقيه و الغربيه و الدقهليه و دمياط

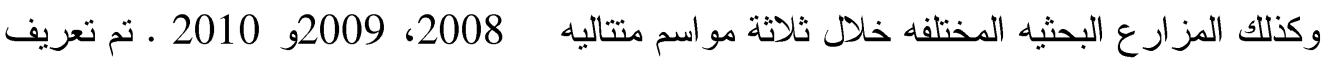
السلالات الفسيولوجية لهذه العزلات على الاصناف المفرقه العالميه تحت ظروف العدوى الصناعية

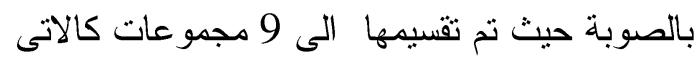

IA (1 race); IB (12); IC (15); ID (45); IE (1); IF (4); IG (22); IH (32) and II (8). وتم استخدام طريقة التو افق الخضرى فى التفريق بين هذه السلالات الفسيولوجية وذلك من خلال انتاج المطفرات nutants على بيئة الكلور ات بمعمل قسم بحوث امر اض الارز بمحطة بحوث

سخا- كفر الثيخ- مركز البحوث الزر اعية. وقد اوضحت نتائج الدر اسة انه تم تقسيم السلالات الفسيولوجية للفطر الى ثمانى مجموعات (VCG 1- VCG8) بناءا على التو افق الخضرى فيما بينها .

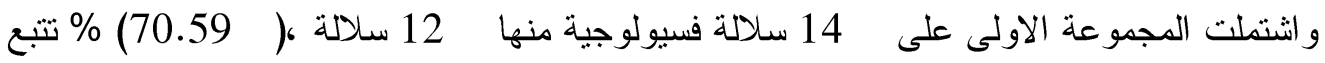

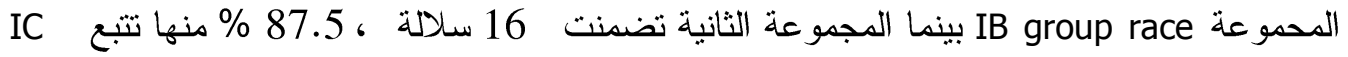
group race وتعتبر المجموعة الثالثة من اكبر المجموعات حيث اشتملت على فسيولوجية 866.36 \% منها تتبع و اشتملت المجموعة الر ابعة على 3 سلالات جميعها تتبع المجموعة IF group race. و واما المجموعة الخامسة فقد تضمنت 23 سلالة فسيولوجية

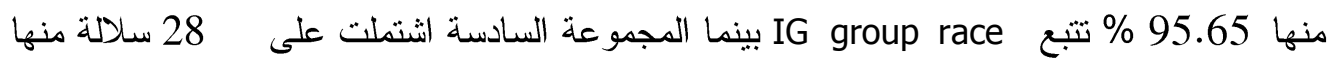
96.43\% تتبع IH group race. وقد انتتملت المجموعة السابعة على سلالات مختلفة فسيولوجيا

وكانت السيادة فيها ل 62.5 \% بينما المجموعة الثامنة فتعتبر اقل

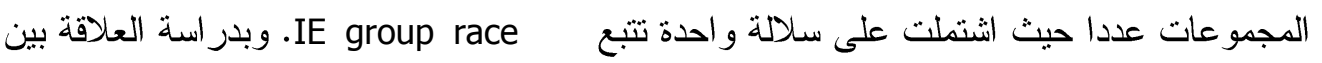
المطفرات بفحص المناطق الفاصلة بين السلالات الفسيولوجية باستخدام الميكروسكوب الالكترونى

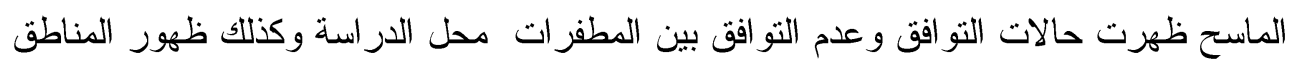
الفاصلة بينها. وبربط النتائج المتحصل عليها من التعريف بالاصناف المفرقة العالمية وطريقة التو افق الخضرى اتضح ان هناك تو افق (تطابق) بنسبة تزاوحت من 62.5 الى 100 \% 